Article

\title{
Application of Industry 4.0 to the Product Development Process in Project-Type Production
}

\author{
Wieslaw Urban *(1), Krzysztof Łukaszewicz@ and Elżbieta Krawczyk-Dembicka® \\ Faculty of Engineering Management, Bialystok University of Technology, Wiejska 45A, 15-351 Bialystok, Poland; \\ k.lukaszewicz@pb.edu.pl (K.Ł.); e.dembicka@pb.edu.pl (E.K.-D.) \\ * Correspondence: w.urban@pb.edu.pl; Tel.: +48-857-469-840
}

Received: 21 September 2020; Accepted: 21 October 2020; Published: 23 October 2020

check for updates

\begin{abstract}
Currently, the concept of Industry 4.0 (I4.0) is reaching most companies by changing the characteristics of their production systems. The aim of this study was to determine the possibilities of applying I4.0 concepts and tools to the product development process in a small- to medium-sized enterprise (SME) — a food processing technology supplier that offers individually tailored solutions. The study employs the case study methodology along with conceptual studies. Based on the available I4.0 concepts/technologies, the areas of the process that could be improved were identified. The study concludes with proposing several modifications in the process in the context of I4.0. Some of the process stages can be shortened by implementing I4.0 tools. It was found that the length of the process can be shortened from 36 to 26 months, and possible gains also include energy savings. Technological tools, referred to as augmented/virtual reality, along with simulations and virtual manufacturing, seem to have particular applicability. The energy savings estimation emerged as a check gate evaluating if technological implementations are justified. Directions for further research with reference to I4.0 and studied processes are determined.
\end{abstract}

Keywords: Industry 4.0; product development process; project-type production; energy savings; case study

\section{Introduction}

Changes in technologies have always influenced significant metamorphoses in business structures. Entire industries have even disappeared while new ones emerged. Similarly, the revolution of digitalisation, automation, autonomous cyber systems, integration, and individualised production techniques, known as Industry 4.0 (I4.0), could also bring about dramatic changes to a business's structures. The revolution of I4.0 has started changing the business world, and there are many indications that the economies of some countries have already stepped into a fourth industrial revolution [1-4]. Manufacturing operations, along with other kinds of operations accompanying them, are on the front line of these technological transformations.

In a production system, the product development process (PDP) plays a particular role; it is one of strategic importance because it delivers tasks for the production system that must meet the recipients' requirements. The PDP affects a production system when an enterprise invents, designs, manufactures, and installs technologies for other companies. In such cases, a PDP is highly integrated with both the manufacturing system and the end-user of the technology. I4.0 solutions can support such a process in many ways, particularly if a company is not a technology giant but a small- to medium-sized enterprise (SME) supplying highly individualised technological solutions to its clients.

The aim of this study was to investigate one PDP at a company that provides individually tailored project production and to analyse how I4.0 can be employed in this process. The researched object is a designer, producer, and installer of individually tailored technologies for the food processing industry. 
It should be noted that the examined enterprise conducts unit production, and each technology is prepared per the customer's order. Therefore, each product is different, and the process of its development requires an individual approach. The research problem is an attempt to identify the tools that can be used by the company to shorten the time needed to introduce a new product to the market and to make an investigated process consume less energy. Several I4.0 tools that would be advantageous to the process are discussed in view of their applicability to this process and for their energetic advantages. The benefits of I4.0 application are also estimated in this study. This is a conceptual study emerging from a case study within a company. The study provides an in-depth discussion of various I4.0 technologies that are applicable to the given PDP, the possible problem areas and the contraindications related to its implementation and integration, and tips on how to solve them. The proposed concept for I4.0 application, according to the preliminary assumption, does not substantially change the machining assets existing at the company.

\subsection{The Industry 4.0 Framework}

Initially, the term Industry 4.0 was associated with the computerisation of production and the dissemination of new network technologies to improve the communication paradigm [5]. Currently, I4.0 is an aggregate notion that encompasses a number of new technological solutions. The literature presents different ways of grouping elements of technological solutions specific to I4.0. An exemplary classification and description of I4.0 key technology groups are presented by Vrchota and Pech [6]. Da Silva et al. [7] present a systematic literature review on innovative issues related to I4.0 in terms of energy efficiency. It should be noted that regardless of the classifications proposed in the literature, common technological elements of the I4.0 concept can be distinguished, such as cyber-physical systems (CPS) [8-13], digital twins (DT) [14], artificial intelligence (AI) and neural networks [15]; the Industrial Internet of Things (IIoT), direct communication between machines (M2M), the Internet of Services [16,17], and the use of large amounts of data-Big Data and analytics [18,19]; methods of collecting and processing large amounts of data, including the use of cloud-based activity [20-23]; horizontal/vertical software integration [24,25]; collaborative and autonomous robots [26-28]; simulation and prognostic techniques [29-31]; additive manufacturing [32,33]; mass customisation [34,35]; augmented reality (AR) and virtual reality (VR) technologies [36-38]. Similar elements of new technological solutions are also indicated by Wolniak et al. [39] and Helo and Hao [40].

Applying certain simplifications to the fundamental idea of I4.0 [41-44], it may be stated that it leads toward the digitisation of production infrastructure controlled by cyber-physical systems in an IIoT environment, where a smooth and collision-free interpenetration also takes place between the real world and virtual reality. The I4.0 concept may also be linked to decentralisation, interoperation, virtualisation, the real-time evaluation of capabilities, service-orientation, and modularity [45-47].

In areas of production automation, vertical integration refers to the integration of various IT systems operating at different hierarchical levels, such as the object level (sensors and drives), the control level, and the production management level. A vertically integrated, networked production system uses cyber-physical production systems to react flexibly not only to changes in needs and warehouse stock levels but also to technical problems. This means that smart factories can effectively use the paradigm of personalised production [48]. Another important determinant is the modularity of the production systems, which should permit flexible reconfiguration.

Increasingly, different customer expectations and intensive competition have led manufacturers to a point where the increase in complexity of production processes and supply chains is greater than ever before. The firm's capability to innovate is the most crucial factor for competitive advantage in highly turbulent market conditions [49]. The use of I4.0 should enable efficient communication and cooperation between people, processes and technologies, influencing the future quality and safety of products [50]. However, this kind of transformation requires transforming operational and information technology into one common network architecture. The application of I4.0 solutions seems to be an opportunity for the SME sector to implement systems that have so far been available only to large 
global companies and have required the creation of individual applications [51]. Further development of intelligent measurement platforms and universal data management software will allow for the creation the complex systems based on ready-made and easily scalable solutions.

Vrchota and Pech [6] emphasise that the current problem is to use new technologies selectively and use them to solve certain issues, often without the overall interdependence of all the systems. It can lead to distortions in the overall energy efficiency. Literature sources, e.g., references [46,52,53], indicate that I4.0 still has a high consumption of resources, raw materials, information, and energy, which is environmentally unsustainable. Estimates show that the manufacturing industry is one of the largest energy consumers among the end-use sectors [54]. According to da Silva et al. [7], manufacturing activities consume about $35 \%$ of the world's total electricity supply, which generates $20 \%$ of the world's total carbon dioxide emissions. Huh and Lee [55] indicate that there is a great need to increase the efficiency of production processes considering the reduction of power consumption and load peaks. Ursic suggests the use of the industrial symbiosis (IS) concept. IS emerged as a collective, cooperative, and multi-industrial approach towards economic and environmental sustainability [56]. Firms participate in IS for exchange of resources, such as byproducts, materials, services, energy etc., in the framework of closed and sustainable cycles. This cooperation contributes to the reduction of required input of materials and energy, as well as a decrease of the output in the form of waste [57]. Rocca et al. [58] indicate the main benefits of I4.0 solutions to achieve the strengthening of the circular economy, namely: (1) digitalisation-supporting companies in process optimisation; (2) simulation with the use of VR supporting process efficiency improvement; (3) innovative ways of monitoring and optimising resource efficiency, leading to the minimisation of energy; and material resources consumption by collecting energy data and creating key performance indicators (KPI) for decision-making. Ferrero at al. [5] states that energy-aware intelligent systems in factories are the basis of both I4.0 and intelligent production. Brozzi et al. [59] declare that technologies associated with the concept of I4.0 are considered as having the unique potential to unlock environmentally sustainable manufacturing [60]; the positive relations to environmental sustainability are detected in terms of load balancing optimisation, leading to a reduction in energy consumption [61-63].

\subsection{Product Development Process}

Contemporary PDP models distinguish (1) the pre-project stage, which analyses market conditions and is coupled with the company's strategy; (2) the pre-design stage; and (3) the post-design stage, which encompasses the monitoring process and withdrawal of the product from the market [64]. Thus, they span the full product life cycle. The idea of using knowledge domains of companies and clients to describe the ability to create successful products or services has often been raised in publications on the subject $[65,66]$.

Currently, there are various suggestions for systematising activities in PDP models in the literature, and there is a clear connection with the domain of knowledge, from which the authors writing about this issue derive. However, as Roozenburg and Eeckels [67] emphasised, in many cases the differences between these suggestions are semantic rather than conceptual [64]. A common feature of most PDP models is the desire to limit the risk of costly feedback loops, i.e., iterations between the stages of the development process. One such approach commonly used in companies is the stage-gate process $[68,69]$, which is based on the belief that formal, structured reviews should be used to ensure that the design is mature enough to allow the transition from one stage to the next.

Amaral, Rozenfeld, and de Araujo [70] proposed a PDP model that aims to integrate engineering and marketing approaches and to organise best practices at work in the scientific and business environments. This model, known as the 'PDP Unified Model', synthetises different scientific perspectives into one theoretical model. The PDP Unified Model includes three macrophases: the pre-developmental, developmental, and post-developmental phases. Each of these macrophases is divided into further phases, activities, and tasks. Although this model presents the stages as a sequence, it is normal that the activities and tasks from multiple phases can generally be carried out 
simultaneously. However, much depends on the type of activities that are undertaken and the resources available. This model also includes, at the end of each stage, dedicated verification and validation activities for advancing to the next stage [64]. Figure 1 shows the PDP Unified Model developed by Amaral, Rozenfeld, and de Araujob [70].

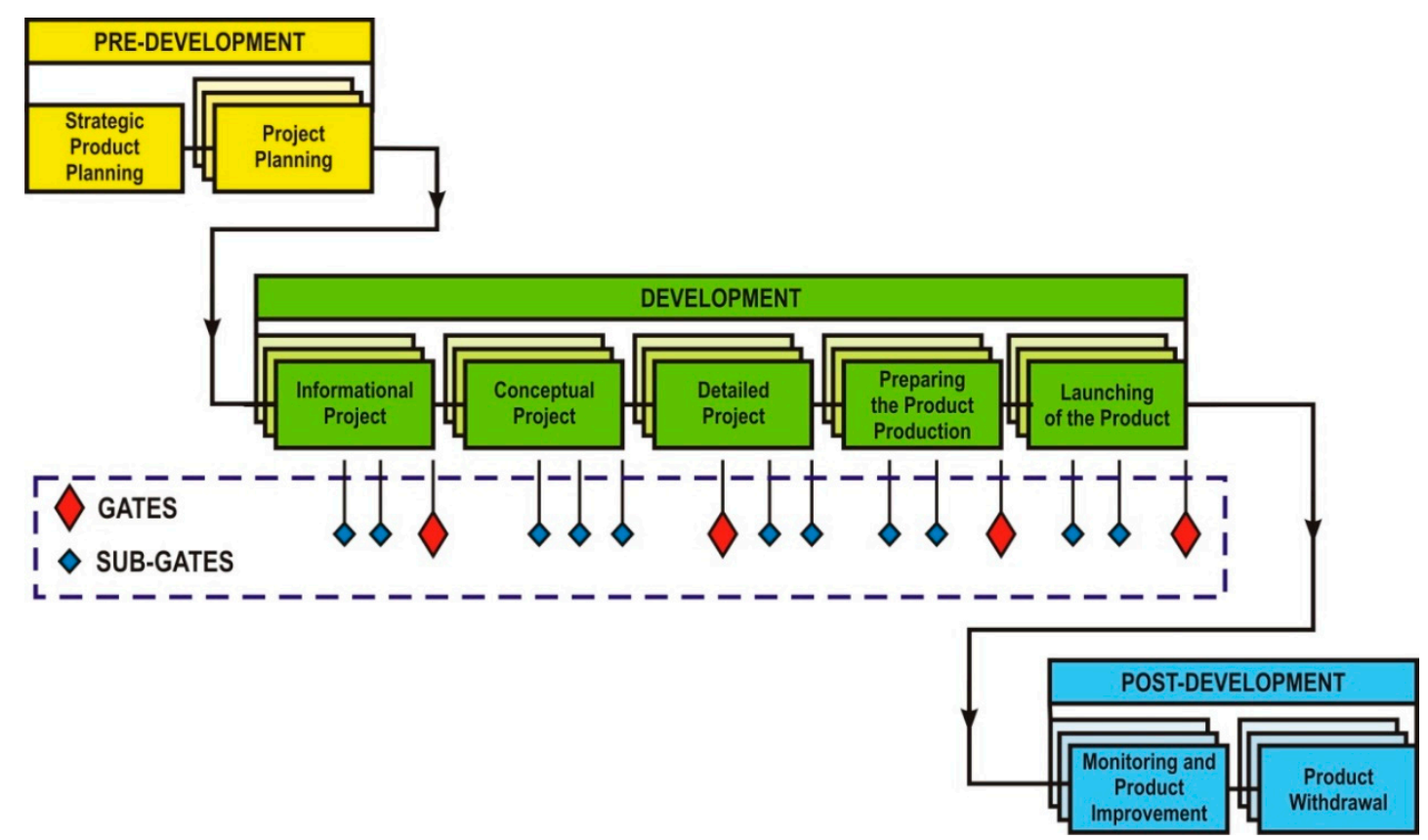

Figure 1. The product development process (PDP) Unified Model. Source: own study.

According to Santos et al. [71], phases of the product development process can be simplified into the following stages: requirement, definition, design, implementation, production, maintenance, and retirement. At the requirement stage, the most effective method for conceptual product development is working with a general team consisting of representatives of marketing, design, production, and management. Designers translate these requirements into specific concerns. In the definition phase, the expectations of all parties involved regarding the outcome of the project are being defined.

The design begins with conceptual drawings, followed by detailed drawings, a model, and finally a prototype. At each stage, the project team is required to present their work to the general team to confirm that the objectives are being met. The production phase is the execution phase and leads to achieving the desired product at the expected costs. The maintenance stage concerns product monitoring after its unstable market launch. While adapting the product, introducing changes and considering the retirement phase, the general team must ask themselves whether potential future sales justify the cost of making the changes. Ultimately, when a product requires such extensive changes to adapt to new customer preferences that the costs become too high, the team must decide to stop production and replace it with a new product. Figure 2 schematically shows the PDP.

We should also mention the BIG Picture model [72], which is a holistic, integrated and cyclical approach to development projects. There are six main paths in this model, where black, red and blue are the most important for technologically uncertain and risky projects. The black path illustrates information gathering, conceptualisation and initial assessment; the red path represents radical innovation and the blue path indicates ground-breaking innovation [73]. The BIG Picture model does not have a fixed sequence of stages and gates but instead uses sequences of working steps and decision stages arranged to suit each type of innovation. 


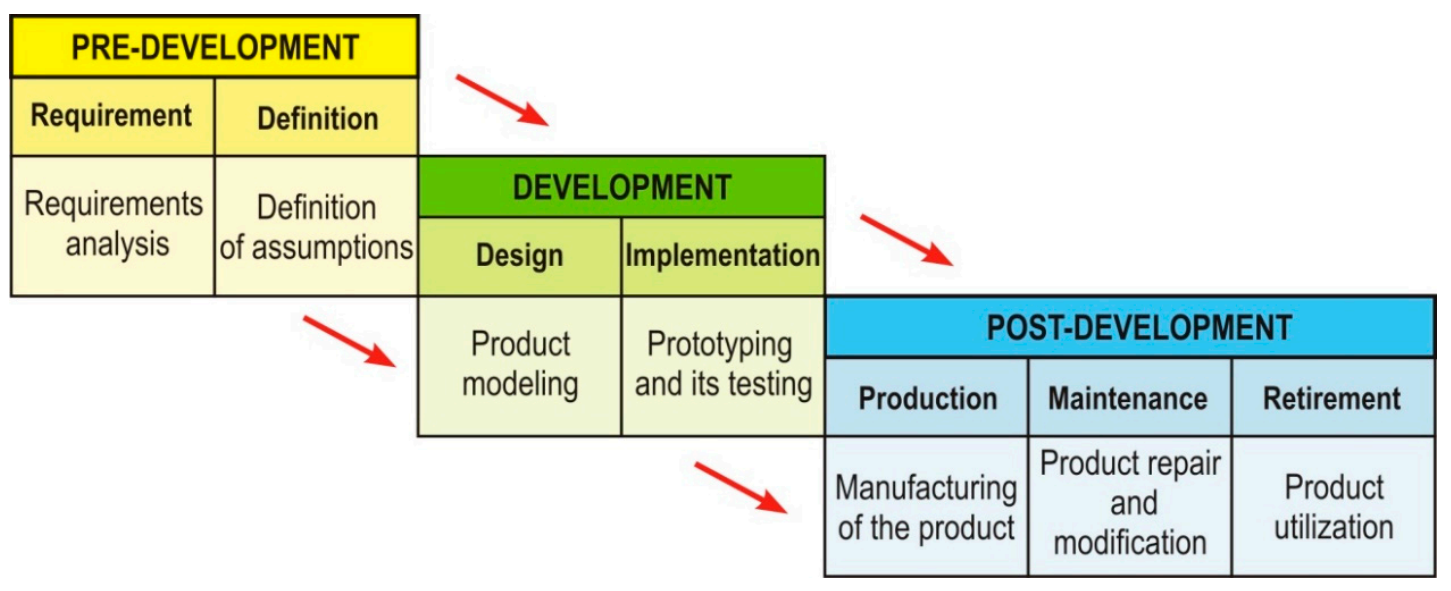

Figure 2. A simplified, classic PDP. Source: own study.

The literature also mentions 'technological process innovation', which very often is interrelated with PDP. Milewski, Fernandes, and Mount [74] perceive this process as a distinctly organisational phenomenon characterised by an internal locus within the company and consisting of such components as the mutual adaptation of new technology and existing organisation, technological change, organisational change, and systemic impact. According to a study carried out at large companies, the technological process innovation life cycle was considered to include four phases: ideation, adaptation, preparation, and installation [74].

In the literature, there are evidences connecting I4.0 implementation to the PDP. Great importance is attached to the PDP supported by VR [75]. As a result of the development of VR technology, the design process is no longer limited only to tools such as computer-aided design (CAD) and rapid prototyping (RP), but it also incorporates VR as a tool for efficient prototype testing [76]. Some scholars argue that virtual reality has reached a high level of development, which offers great benefits in the field of industry [77].

For example, Feeman et al. [78] have examined VR to assess the possibility of making a prototype in VR. They have concluded that modelling in virtual reality is possible and that it exhibits many benefits over CAD systems, including greater satisfaction, the potential for accelerated or increased creativity and idealisation, reduction of obstacles in the addition of features, improvement of the feeling of scale of models, and increased physical activity in the workplace [78].

The PDP process is evolving, especially in I4.0 conditions. Bickel et al. [79] have demonstrated this by presenting a simulation of changes in the structure of people involved in PDP. Designers are increasingly becoming product development engineers. Product and process simulation is becoming more and more important, and the number of people involved in these domains is increasing. The number of test engineers and engineers directly involved in the manufacturing process (production) will decrease. We can notice the key role of knowledge and the exchange of various data on these processes. With proper and efficient use of the data provided, it is possible to decrease the development time and increase the quality of new products [79].

The issue of energy efficiency and energy savings, along with I4.0 exploitation, being very popular and of primary importance in manufacturing industries [7], when referring to the PDP, is currently actually rarely studied. Various research teams have proposed approaches and methodologies that attempt to quantify energy consumption at the unit process level [80], but the issue of consciously seeking to optimise energy consumption as a whole (concept, design, manufacturing) is a subject that receives very little attention in the literature.

Undoubtedly, the idea of I4.0, along with constantly emerging new technologies in this area, influences and will affect the PDP in a significant manner. The impact of I4.0 on the PDP has not yet been systematically analysed [81] and represents a completely new challenge with many open questions [82]; primarily, the issue of what kind of technologies involved in I4.0 are particularly 
implementable to the PDP. Another issue is how to effectively use I4.0 tools in the PDP and what kind of effects can be achieved. And finally, how the energy aspect can be placed on the PDP and how I4.0 can be exploited in the whole PDP in terms of the energetic advantages. All of them look to be immensely important and encourage investigation. A particular shortage of research is observed when referring to the SME sector.

\section{Research Methods}

\subsection{Employed Methods}

In this study, the case study method and the conceptual studies were applied. The case study method allows a comprehensive and broad view of complex issues. It is often used in studies of manufacturing systems, e.g., references $[83,84]$. The conceptual work presented in this study significantly borrows from the conceptual design approach, which is widely employed in many fields, being practiced in engineering, product development, and manufacturing systems [85-87]. According to the literature, conceptual design is modelled using precise and neutral concepts that stem from needs or ideas [85]. A design concept defines and describes the principles and features of a system [87].

The point was to recognise the exact flow of the PDP in a company and its main characteristics, peculiarities, and circumstances. The investigation of the company involved many visits and data gathered from several sources: observation of the production process, direct interviews with managers, and the analysis of technological documentation. The flow-chart technique was employed to visualise the investigated process. The main followed parameter was the duration of subsequent PDP stages based on observations and information obtained from documentation. The comprehensive functional diagnosis of PDP was crucial for a deep consideration project-type production specificity [88]. The comprehensive process understanding has made an input for the next stage of the study on possible I4.0 tools implementation in this process. The obtained data along with recognised process peculiarities allowed conceptual considerations and deep references to the reality in appraisement of variety of I4.0 technologies. In the conceptual part of the study, the following question was asked: what specific I4.0 tools can be applied to this PDP, and can they bring the befits in terms of process flow, perceived as its efficiency and duration, along with effects related to energy?

\subsection{Studied PDP}

The company in question specialises in delivering individually tailored technologies to food manufacturers. It also provides machining services, tooling services and automation for the client's production processes. The company therefore belongs to the SME sector. It applies several technologies for metal processing, including machining, plastic working, electro-erosive machining, etc. The in-depth study concerned the technology of a pet food packing line, which the company had created intending to install it in a particular client's facility, and, after some modifications, to sell it to other food processing companies.

The model of the PDP for the automatic packing line built by the company is shown in Figure 3. The first step consisted of the development of guidelines along with technical and structural assumptions. During this stage, the specific tasks and functions the device had to perform were listed, the structure was defined, and the materials and components were selected. Based on these specifications, the developers created a parametric model of a new technology (device). The next step was to analyse the labour and cost intensity of the newly designed technology. The result was a decision either to proceed with the implementation of the design or to go back to the assumptions stage (see the loop in Figure 3).

Based on the results of the modelling work, the company began designing the process of building a new product. The previously designed models contained only frameworks and particular nodes of the technology, so the design for its implementation demanded a huge amount of creative work. Many sources (patent records, industry fairs and online services) were explored to identify and check possible solutions for many detailed technical issues, including execution methods. The technical 
specifications were developed for emerging technology, and the materials and necessary components were also gathered to proceed to the next stage.

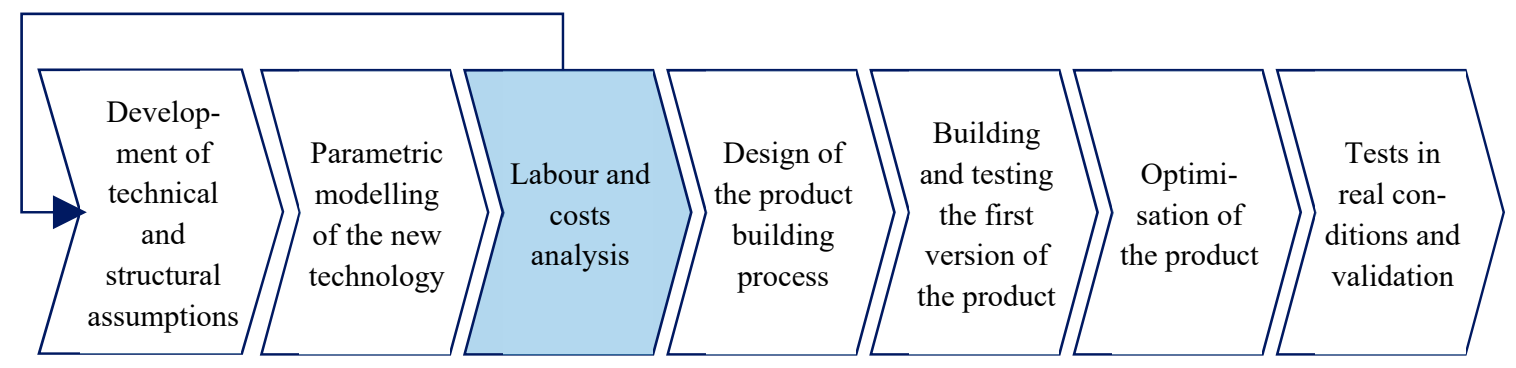

Figure 3. The PDP of automated lines for pet food packing. Source: own study.

Building and testing the first version of the production line for pet food packing was the next step in the PDP (which lasted for 12 months). This work led to the discovery of previously undetected structural errors, and the necessary corrections were carried out. The testing took place under simulated operating conditions. The next step was to optimise the developed product. Several changes and adjustments were performed at this stage. Eventually, the final version of the product emerged. This version was installed at the client company's facility and tested under real conditions. The technology was validated under the initially established assumptions. The whole PDP lasted 36 months. An in-depth tracing of the whole PDP allowed us to recognise that the energy-related issues are not practiced within in. In the process, there are no dedicated guidelines, procedures, or techniques to calculate and/or intentionally shape energy consumption during the process's stages as well as in the product itself. It looks like a particularly important challenge for the studied process, along with I4.0 implementation.

As presented above, the PDP in the study is not completely typical of the processes elaborated in the literature. This is a real PDP; in fact, it contains the pre-development stage. However, it looks simplified compared to the literature models-the development stage is subsequently mixed and overlaps with the manufacturing stage, which looks as though it were influenced by the project production type. The PDP ends with the launch/installation step. The company under study is a technology producer, and this kind of business requires close and frequent consultation with the technology recipient throughout the PDP. During the field investigations, attention was paid to the tools that the company used in the PDP, and the time taken by individual activities was analysed. Employees were also asked about the factors influencing the duration of process steps. The obtained information was used to prepare the concept of application I4.0 tools for this process.

\section{Results}

The PDP described above is a typical representative of Industry 3.0 [89] —although IT is employed, alongside automated machining, all of these instances are run and coordinated as separate entities. This refers to all critical fields in the process: first, the creation sphere; then testing and analysis; and finally, hard machining/processing. Considering that this case represents project-type production, where the production volume is very small, and the company-being an SME—does not have many employees or much revenue, it is expected that I4.0 will be implemented under distinctive conditions that will ultimately affect the content and scope of possible applications.

The product development stages/steps stated above, including the interaction and information flow between them, were diagnosed regarding the possibility of beneficially implementing I4.0 solutions. First, information flow is an issue where I4.0 can make a significant contribution between processing unit interfaces, functional software types, and humans. Among I4.0 tools, Asdecker and Felch [90] mention integrated databases (IDs), which integrate disparate sources of data from different departments and functions within an organisation. Cloud computing is an option in this case, and although it is not exactly indispensable, it could be beneficial to the process. An ID can be used starting 
from the stage of parametric modelling of the technology. Cooperation between departments would enable early reaction to the variable factors that shape the process.

One-off production of a complex and advanced product requires many experimental solutions and several changes and modifications. Therefore, computer simulation (S) appears to be potentially highly beneficial in this PDP. S has been used to model the optimum parameters for an industrial conveyor (for example, in references [91,92]). The approach described by Troll et al. when modelling the movement of products is compared with the conventional approach, showing that using parameters determined by a computer simulation led to an increase in process efficiency. Salkin et al. [93] note that simulations can be adapted in product development, testing and test optimisation, production process development and optimisation, and facility design and improvement.

In the case under consideration, the use of $S$ is recommended chiefly in the engineering phase for structural design, selecting materials and selecting the optimum parameters for the final production process. In the future, consideration may also be given to the use of $S$ in the operations of the company to which the project is addressed. These simulations can use data gathered in real time to reflect the physical world in a virtual model, which may encompass machines, products and people. This will enable the operators to test and optimise the settings of a machine for a subsequent product in the virtual world before any physical change is made, thus shortening the time required to configure the machine. One example is the virtual machine solution proposed by Siemens, a German machine tool manufacturer, which can simulate the machining of a part using data from a physical machine. According to Rüssmann et al. [94], this reduces the time required to set up the actual machining process by as much as $80 \%$.

Due to the highly individualised approach to the product and, consequently, the need for very close cooperation with the client, visualisation technologies (VTs) are particularly useful. I4.0 supposes two technology bundles associated with visualisation, namely, augmented reality (AR) and virtual reality (VR). The former is associated with graphics, sounds, and touch feedback added to the natural world; the latter is a different concept in which one inhabits an entirely virtual environment [95]. These technologies rely on video-based adaptation taking advantage of a camera that supplies augmented information and provides particular sensations by a special display worn by the user or project-defined objects [96]. The product design stage provides an opportunity to greatly benefit from the use of these technologies; they prevent errors that could occur at this stage and at other manufacturing stages [95].

An important feature of VR/AR that distinguishes it from traditional computer simulation is the constant presence of the user in the virtual environment. In relation to the case under discussion, VR techniques will enable a model of a device, initially created in a CAD system, to be placed in a freely designed virtual environment in the presence of other virtual objects. This approach enables changes to be made to the design in an effective manner and improves communication with the customer. AR technology, where a virtual object is visualised against the background of a real spatial context, and the view in which it is presented depends solely on the position of the user relative to the object being designed [97], which may be used for the final presentation of a design and for verification of the design assumptions.

Another postulate of I4.0 is partner integration (PI) by digital tools and channels. Asdecker and Felch [90] mention industrial digital ecosystems which integrate customers, suppliers, and other external partners of a company. They postulate an end-to-end data/information flow that is built from multiple sources and enables real-time analytics. However, in the case of close cooperation with a business client involving a long-term cooperative design of an advanced product, where many product components are sub-supplied by technologically advanced producers of automation, partner integration strongly affects the process. Assuring consistency in the information, in all communication channels and at all points of contact with the customer, is a fundamental condition of success in an I4.0 transformation.

Virtual manufacturing (VM) is another of the pillars of I4.0. Virtual manufacturing began as a way to design and test machine tools, but it has expanded to encompass production processes 
and the products themselves [95]. This is an idea that covers a variety of tools and methods, from computer-aided design to rapid prototyping. VM also brings great expectations in terms of energy saving in the PDP, particularly in a manufacturing step. Even though the idea is a broad one, some subsystems/functionalities may be supportive in the PDP in the current study. Considering that VM serves to test production in a virtual environment [98], it can support the PDP in terms of analysing the manufacturability of parts. The product peculiarity supposes that it is not repetitively manufactured, so that the VM can be used several times in modelling the technology of product manufacturing.

The implementation of the solutions described above will allow the company to improve the product development process, improve its efficiency, and significantly reduce the time of this process. This will positively affect the quality of cooperation with the client and thus contribute to the improvement of the company's competitiveness on the market. The implementation of solutions should also result in a noticeable reduction in energy consumption due to the use of more environmentally friendly solutions and shorter process time. The discussion of particular I4.0 utilisations will be conducted in the following section.

\section{Discussion}

Leurent et al. [99] have analysed more than one hundred cases of production plants and selected 16, which they called 'Lighthouses of the Fourth Industrial Revolution'. These are the organisations that have moved from the level of pilot programmes to full technology integration and execution of the I4.0 concept. In each of them, the researchers have identified 10 to 15 areas subject to change and have distinguished five key areas. In the report, they were presented together with a description of implementations and their effects on the organisation-for example, their impact on overall equipment effectiveness (OEE), product quality, time-to-market, or production and logistics costs. The chart published in the report shows significant differences in the KPI scores achieved by the companies. The large discrepancy in terms of increasing productivity $(10 \%-200 \%)$ and productivity $(5 \%-160 \%)$ is noteworthy. In terms of shortening production times and time-to-market, the differences are decidedly smaller and amount to $10 \%$ to $90 \%$ and $30 \%$ to $90 \%$, respectively.

Based on a review of the literature and the analysis of the PDP at the company under study, improvements were proposed using specific I4.0 solutions, which will enable measurable benefits to be achieved at individual steps of the process. Table 1 lists the proposed solutions with an indication of the steps at which each proposal is most relevant.

Table 1. Industry 4.0 (I4.0) solutions that may provide benefits at particular steps of the PDP.

\begin{tabular}{|c|c|c|c|c|c|c|}
\hline \multirow{2}{*}{ Steps } & \multicolumn{6}{|c|}{ I4.0 Solutions } \\
\hline & ID & $\mathrm{S}$ & VT/AR & VT/VR & PI & VM \\
\hline $\begin{array}{l}\text { 1. Development of technical and } \\
\text { structural assumptions }\end{array}$ & + & & & + & + & \\
\hline $\begin{array}{l}\text { 2. Parametric modelling of the } \\
\text { new technology }\end{array}$ & + & + & & + & + & + \\
\hline 3. Labour and costs analysis & & & & + & + & \\
\hline 4. Design of the product building process & + & + & + & & + & + \\
\hline $\begin{array}{l}\text { 5. Building and testing the first version } \\
\text { of the product }\end{array}$ & + & & + & & + & + \\
\hline 6. Optimisation of the product & + & & + & & + & + \\
\hline 7. Tests in real conditions and validation & & & + & & + & \\
\hline
\end{tabular}


ID and PI are recommended for most of the stages of the product development process. Gathering information and analysing the design and technological data, plus the possibility of modifying the structural model, require the use of a common virtual environment and a database with precisely defined levels of access. The aim is to enable simple, authorised access to the design data by selected, interested parties (the customer and the manufacturer).

Step 1 of the process (the development of technical and structural assumptions) involves intensive communication with the customer (the party placing the order). To develop a joint platform for communication between the customer and the manufacturer, it is recommended to improve the methods of communication: placing orders using special data forms linked to the parameters of a geometric model and stored in a shared database (ID: fulfilment of the PI idea), advanced visualisation methods (VR), and the determination of the types and quantities of material requirements (ID). The proposed improvements will lead to a more precise definition of the initial design assumptions to satisfy both parties, easier presentation of the design in relation to the actual conditions of future use of the designed object and reduction in the time required to define the initial assumptions. Moreover, the use of VR techniques will provide support for designers and process engineers-for example, in relation to the general assumptions about the mutual positioning and geometry of component elements and correct accounting for the properties of the construction materials. Thanks to the usage of computer databases (ID), including construction materials databases, it is possible to select materials taking into account their energy consumption and environmental impact. For example, the Autodesk Inventor module, developed jointly with Granta Design Ltd., called Eco Materials Adviser offers such possibilities. This tool allows designers to optimise the selection of materials based on information about their environmental impact and production costs in order for manufacturers to make the best decisions and solutions that meet environmental requirements [100]. An example of the use of VR can be found in KIA Motors [101], who have introduced a new system in their research and development centre to use virtual reality for car design. Thanks to this solution, the development of new models can be reduced by $20 \%$, and the associated costs will be lower by $15 \%$. Through the use of VR technology, up to 20 people can participate in the project evaluation process simultaneously, which significantly facilitates collaboration between teams of different specialists who can work from design centres located in different parts of the world. Considering the lower level of experience and technological advancement of the company in the current study in comparison with KIA Motors, it is estimated that the use of the proposed solutions at this stage will reduce the time required to prepare a design by approximately $10 \%$.

In Step 2 (the parametric modelling of the new technology), it is recommended to apply the methods of concurrent engineering and simulation environments (S), including dynamic simulations. At this stage, it is expected to reduce the energy consumption resulting from the lack of the necessity to create a physical prototype and to perform tests on physical objects. In terms of design, more normalised elements can be selected, and other means of standardisation can be employed, which also leads to reduced energy consumption. $\mathrm{S}$ can also help to solve typical production challenges in the context of I4.0, which include an investment impact assessment, optimisation/scheduling of production planning, facility design, capacity planning, process improvement, bottleneck analysis, production line balancing, resource allocation, improving material flow and inventory planning, and experimenting with lean manufacturing techniques, as pointed out by Butt [102]. Fric et al. [103] presents some principal dilemmas and challenges that need to be undertaken when conducting future research on industrial symbiotic networks using existing and efficient computer software tools. The information in the Encyclopaedia of Business [104] suggests that Boeing's use of the CAD system in the entire design process of the 757 aircraft reduced the total number of assembly hours by one-third, and the analytical functions of the CAD system reduced the number of working prototypes from 12 to three for the 747 aircraft. Product data management software should be used in the collection and sharing of design documentation, and documentation in 'paper' form may even be eliminated altogether. This will facilitate and simplify the evaluation of the impact of the materials used on the environment and allow 
for direct viewing of the object designed by specialists in various fields. The model developed may undergo initial evaluation using VR techniques. Specialists will be able to react rapidly (at an early stage) in relation to key elements of the design. The solution worked well for John Deere, which uses augmented reality to allow customers to test and provide feedback on early design concepts, so they can adjust and redevelop their designs. The company estimates that having its engineers use virtual reality simulations to design the air-handling subsystem on its JD 7760 cotton harvester reduced the design cycle time from 27 months to nine months [105]. After applying the proposed solutions in the company being studied, it is expected that the document flow will become faster and more efficient and that the waiting time in the document flow feedback loop will be reduced by approximately $25 \%$.

Step 3 (labour and costs analysis) involves decision-making and enabling preliminary verification of the justifiability of the current design and its conformance to its goals. This activity takes the form of a logical function, creating a feedback loop obliging the manufacturer to re-analyse the technological assumptions (input parameters). This stage should also consider an analysis of costs related to energy use. Gong et al. [106] claim that minimising energy consumption and production process costs can be achieved by manufacturing companies in a cheap way. They present their energy model based on a case study of the plastic bottle production process and the production planning based on real-time electricity price data. In this model, the optimal idle mode is automatically selected between production loads (e.g., power off, idle). The authors show that the schedule of common energy costs and minimising labour costs reduces the total costs by $12 \%$ compared to the classical schedules. The experience of DiaCom, where it was necessary to frequently modify existing membrane designs, shows that by using Solid Edge synchronous technology instead of traditional history-based processes, DiaCom has noted a reduction in the time required to introduce changes of up to $50 \%$ compared to the previous design process [107]. In the authors' view, implementation of the above proposals will significantly reduce the number of repetitions in this loop, particularly when VR and PI techniques are used.

In Step 4 (design of the product-building process) and Step 5 (building and testing the first version of the product), it is recommended to use computer-aided manufacturing (CAM) software environments to generate machining programmes for $\mathrm{CNC}$ machines with the ability to simulate machining in real time (VM). This will lead to a simplified development of the technological documentation. Moreover, the direct transmission of data (machining programmes) to $\mathrm{CNC}$ machines will make the operations of technological units significantly faster and more effective, and it will enable more precise supervision of the progress of work. With a VM, a better layout of the manufacturing processes, which reduces energy consumption, e.g., high performance cutting (HPC), can be achieved. Easily accessible data can be obtained from 'energy-conscious' devices and systems, which offers a more efficient picture of energy consumption and demand as production data. This level of energy information increases the amount of collected data, but also enables its efficient use in correlation with already collected data. Gontarz et al. [108] present energy and resource-monitoring architecture based on intelligent sensors. This method classifies the energy behaviour of machine components in three modes: fixed (energy behaviour independent of the process and most often used to maintain a specific state of the machine tool), controlled fixed (periodical on/off mode supervised by the programmable logic controller or external devices), and variable (process-dependent). Similarly, the work of Matsuda et al. [109] presents a method for the individual monitoring of machines and creating a catalogue library, the aim of which is to build a virtual factory for production simulation. Mawson and Hughes [110] state in their publication that investing in energy-efficient technologies and implementing smart control technologies can reduce energy consumption by $50 \%$ as opposed to operational improvements that can only reduce it by $10-20 \%$.

In their paper, Bugno and Szalaty [111] presented the case of using CAM software at EthosEnergy Poland S.A. High efficiency machining was implemented there in the manufacturing of flexible beams for generator bodies. With the use of 3D modelling and CAM, geometric analysis was performed, and the most optimal tool was selected, thanks to the $20 \%$ reduction in machining time that was achieved, eliminating drilling operations. The application of a virtual prototype with the use of AR will simplify 
the procedure of gathering data from tests and will increase the number of available measuring points and the precision of the data in Steps 4 and 5. These actions may be expected to lead to reductions in the costs of creating and testing the first version of the technology. This can be seen in the Ford 3D Sand Printing Lab. A single binder jet print run can take as little as one week or up to one month, depending on the job size and deadline. Conventional sand moulds would take eight to ten weeks [112].

Considering that the proposed improvements, encompassing the previous steps, enable the optimisation of design and production based on multiple criteria and are carried out on an ongoing basis, it may be concluded that it is appropriate to eliminate Step 6 (optimisation of the product) and to combine Steps 4 and 5 from the original version of the process diagram. Instead of Step 6 of the studied process, it is proposed to perform the check of the condition whether the previously implemented stages meet the set criterion of energy efficiency; this would be a verification gate, if output is negative going back to the previous steps will be necessary. It is estimated that, as a result of these modifications in relation to PI, AR, and VM, the time required for these Steps (4-6) in the development of a new product may be reduced by approximately $60 \%$, and the overall time of the PDP in the study may be reduced by approximately $30 \%$. Such an estimation seems to be consistent with literature reports (e.g., Roszak [113]), where it is predicted that the time to launch a new product on the market can be shortened by $20 \%$ to $50 \%$. In addition, the use of new technology and IT platforms, including knowledge bases, may result in reducing traditional product development cycles by up to $90 \%$, as suggested by the data presented in a report by Leurent et al. [99]. Estimated durations of the product development process with the use of I4.0 concepts are given in Table 2. The duration of Step 7 (tests in real conditions and validation) is not expected to be changed by the use of I4.0 solutions because the time of testing is defined by the company based on their previous experience, accounting for the probability of production faults that are caused by the continued operation of the device appearing.

Implementation of the proposed improvements, particularly with the use of PI and ID, will make gathering and analysing data and supplementing the database more effective. In the company, this will make work on subsequent projects easier and faster, and it will enable more efficient introduction of required changes during the modification and repeated verification of the design. It should be noted that a very significant effect on the total time required to develop the process is achieved thanks to the use of PI, which ensures the consistency of information at all levels of cooperation between the company and its customer. According to Rüssmann et al. [94], the use of integrated production processes resulting from I4.0 capabilities will reduce production cycle time by up to $30 \%$. Integrated production processes will allow the use of cost-effective production of small batches, and the use of robots, intelligent machines and products that enable mutual communication in real time will affect the autonomy of decisions and production flexibility. In the opinion of Rüssmann et al. [94], I4.0 will increase productivity in component manufacturing by $4 \%$ to $7 \%$.

It should be remembered that the considerations presented here represent a somewhat simplified approach to the problem of implementing I4.0 solutions in the production process of a given company, and they omit many other available capabilities that the I4.0 concept offers. One of the assumptions of the research was to reduce one-time investment costs, without considering changes in the company's available infrastructure. The implementation of I4.0 in every area of the company's operations ought to be a continuous process, helping to create a competitive advantage and to maintain the company's position on the market. The firm's success may be dependent on its ability to make sufficiently rapid use of the technological proposals described and on properly realising its relational potential. 
Table 2. Estimated durations of the PDP steps at present and following the introduction of I4.0.

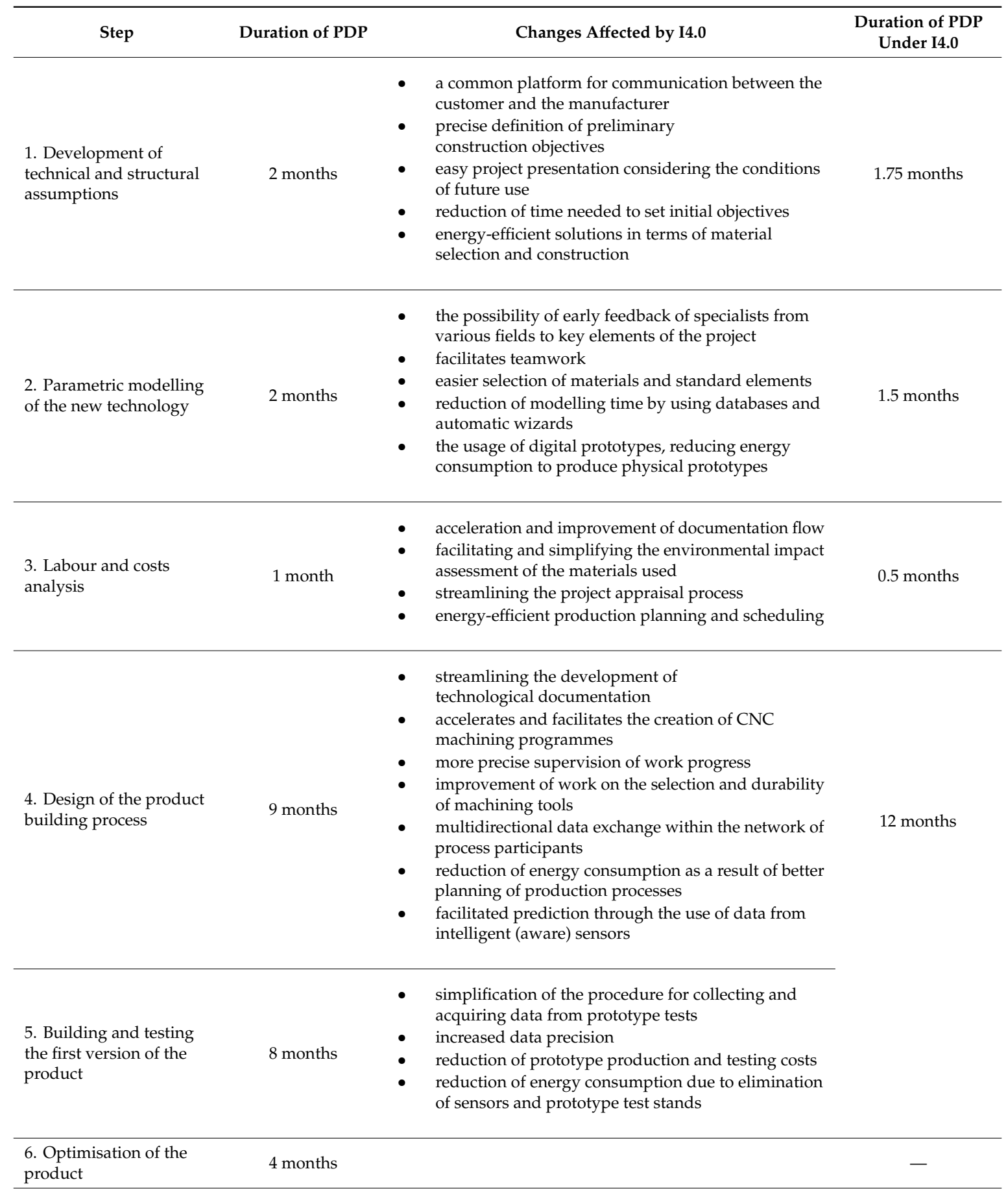

\begin{tabular}{|c|c|c|c|}
\hline $\begin{array}{l}\text { 6. Optimisation of the } \\
\text { product }\end{array}$ & 4 months & & - \\
\hline $\begin{array}{l}\text { 7. Tests in real conditions } \\
\text { and validation }\end{array}$ & 10 months & $\begin{array}{l}\text { - } \\
\text { facilitates and accelerates work on } \\
\text { subsequent projects } \\
\text { possibility of verification by specialists from } \\
\text { various fields } \\
\text { - } \quad \begin{array}{l}\text { collecting data from conscious sensors for use in } \\
\text { product improvement }\end{array}\end{array}$ & 10 months \\
\hline Total PDP time: & 36 months & & 26 months \\
\hline
\end{tabular}




\section{Conclusions}

The use of I4.0 solutions in the PDP in this study may provide a significant reduction in the time of the process, which is estimated to be as much as 10 months, and may facilitate cooperation between the company and its customers. Skilful management of technological changes, integrated with the company's business processes, enables it to maintain a competitive advantage. The organisation's success appears to be founded on innovation, which in the conditions of I4.0 is made possible especially by innovations based on AR/VR and S technologies. In the perspective of I4.0, $\mathrm{S}$ is a tool that supports in following the findings of various parameter changes and in visualising the decision-making process. Therefore, simulation tools can be used together with other fundamental technologies of I4.0 [93]. S is complemented by AR/VR technologies, which enable designers and customers to 'see and test' the finished product before it is physically produced, which is of great value from a marketing perspective, and by the same token contributes to the building of relationships with customers.

The main contribution of this study is to demonstrate the feasibility of new technologies offered by I4.0 to improve the efficiency of the PDP, at the same time the problem of energy consumption has been investigated. The empirical study has shown that this issue has been neglected in investigated PDP. It is stated that the issue of energy consumption in the implementation of the development process is a criterion for assessing the advisability of implementing I4.0 solutions. Undoubtedly, the new solutions increase the efficiency of the process, measured mainly in terms of duration, but it is equally important to consider the reduction of energy consumption, which is forced by today's environmental, economic, and legislative challenges. Taking these challenges into account, in order to achieve sustainable development, a detailed analysis of the implemented I4.0 elements is always necessary, including the proper management of energy consumption. By using monitoring systems and raising the awareness of technology users, it is possible to optimise energy savings and energy efficiency by up to $30 \%$ similarly as demonstrated in a source [108].

An in-depth study of the PDP in a company and wide conceptual deliberations made it possible to identify a number of challenges regarding future research directions. First, the study presents the need for intensive investigation of the entire PDP process in terms of the potential improvements by I4.0; what was carried out in this study is only a concept. However, empirical investigations of particular I 4.0 tools are indispensable. Second, the study turns the attention to individual product manufacturing and project-type production. It demonstrates the immense potential of I4.0 implementation to the production of this type. However, this is only the beginning; the implementation of I4.0 to project-type production of its different characteristics needs to be more widely studied. There are no doubts that the individual production type will be more and more popular. Third, energy issue is not considered deeply enough with reference to the PDP. Product development is the most appropriate step to consider the energy savings, which will be possible/performed on further steps of the product, including the manufacturing process. How to rebuild the PDP to assure that the energy affairs are properly carried out and what kind of new technological tools should be implemented, these are right questions. From a managerial viewpoint, the study implies the necessity to improve the knowledge and awareness of I4.0 technologies in SMEs, the technologies becoming crucial for competitiveness success, and can bring many advantages in terms of processes efficiency and energy savings. The proper selection of software and its implementation, including time for employees to develop appropriate capabilities, also remains as an open question.

The main limitation of the study comes from the methodology used, as a conceptual deliberation involves the risk of moving too far away from real production processes and facilities. To diminish this risk, the study is deeply rooted in the comprehensively studied PDP in a company. Additionally, each of the recommended I4.0 tools has been widely reviewed in terms of practical experiences of its utilisation in the industry. However, the conceptual nature of this study has not allowed for validating the solutions in practice. Additionally, the study is burdened by inherent weaknesses of the case study method. The most important of them are a potential researcher bias along with misunderstanding of what was observed in studied object $[114,115]$, these were minimalised by triangulation, all of 
researchers visited studied business object. Despite its limitations, the study provides substantial value in demonstrating I4.0 implementation in the main processes of a project production SME. The concept of I4.0 implementation presented herein is thought to be very important at a time when I4.0 can expand to smaller companies, equipping them with competitive tools and increasing their productivity and effectiveness. As presented above, I4.0 can be implemented in a manufacturing SME and can be greatly beneficial.

Author Contributions: Conceptualization, W.U.; methodology, W.U., K.Ł., and E.K.-D.; validation, W.U., K.t. and E.K.-D.; formal analysis, W.U., K.Ł., and E.K.-D.; investigation, W.U., K.Ł., and E.K.-D.; data curation, W.U., K.Ł., and E.K.-D.; writing—original draft preparation, W.U., K.Ł., and E.K.-D.; writing-review and editing, W.U., K.Ł., and E.K.-D.; visualization, W.U., K.t., and E.K.-D.; supervision, W.U.; project administration, W.U. All authors have read and agreed to the published version of the manuscript.

Funding: This research was funded by a grant from the Minister of Science and Higher Education received by the Bialystok University of Technology, grant number WZ/WIZ-INZ/3/2019.

Conflicts of Interest: The authors declare no conflict of interest.

\section{References}

1. Dalenogare, L.S.; Benitez, G.B.; Ayala, N.F.; Frank, A.G. The expected contribution of Industry 4.0 technologies for industrial performance. Int. J. Prod. Econ. 2018, 204, 383-394. [CrossRef]

2. Kagermann, H.; Helbig, J.; Hellinger, A.; Wahlster, W. Recommendations for Implementing the Strategic Initiative INDUSTRIE 4.0: Securing the Future of German Manufacturing Industry; Final Report of the Industrie 4.0 Working Group; Forschungsunion: Frankfurt/Main, Germany, 2013.

3. Liao, Y.; Deschamps, F.; de Freitas Rocha Loures, E.; Ramos, L.F.P. Past, present and future of Industry 4.0-A systematic literature review and research agenda proposal. Int. J. Prod. Res. 2017, 55, 3609-3629. [CrossRef]

4. Schwab, K. The Fourth Industrial Revolution; Crown Publishing Group: New York, NY, USA, 2017.

5. Ferrero, R.; Collotta, M.; Bueno-Delgado, M.V.; Chen, H.C. Smart Management Energy Systems in Industry 4.0. Energies 2020, 13, 382. [CrossRef]

6. Vrchota, J.; Pech, M. Readiness of Enterprises in Czech Republic to Implement Industry 4.0: Index of Industry 4.0. Appl. Sci. 2020, 9, 5405. [CrossRef]

7. Da Silva, F.S.T.; da Costa, C.A.; Crovato, C.D.P.; Righi, R. Looking at energy through the lens of Industry 4.0: A systematic literature review of concerns and challenges. Comput. Ind. Eng. 2020, 143, 106426. [CrossRef]

8. Bagheri, B.; Yang, S.; Kao, H.-A.; Lee, J. Cyber-physical Systems Architecture for Self-Aware Machines in Industry 4.0 Environment. IFAC-Pap. 2015, 48, 1622-1627. [CrossRef]

9. Garetti, M.; Fumagalli, L.; Negri, E. Role of ontologies for CPS implementation in manufacturing. Manag. Prod. Eng. Rev. 2015, 6, 26-32. [CrossRef]

10. Jeschke, S.; Brecher, C.; Meisen, T.; Özdemir, D.; Eschert, T. Industrial Internet of Things and Cyber Manufacturing Systems. In Industrial Internet of Things; Jeschke, S., Brecher, C., Song, H., Rawat, D., Eds.; Springer: Cham, Switzerland, 2017; pp. 3-19. [CrossRef]

11. Pereira, A.C.; Romero, F. A review of the meanings and the implications of the Industry 4.0 concept. Procedia Manuf. 2017, 13, 1206-1214. [CrossRef]

12. Qin, J.; Liu, Y.; Grosvenor, R. A Categorical Framework of Manufacturing for Industry 4.0 and Beyond. Procedia CIRP 2016, 52, 173-178. [CrossRef]

13. Vaidya, S.; Ambad, P.; Bhosle, S. Industry 4.0-A glimpse. Procedia Manuf. 2018, 20, 233-238. [CrossRef]

14. Tao, F.; Cheng, J.; Qi, Q.; Zhang, M.; Zhang, H.; Sui, F. Digital twin-driven product design, manufacturing and service with big data. Int. J. Adv. Manuf. Technol. 2018, 94, 3563-3576. [CrossRef]

15. Kozik, P.; Sẹp, J. Aircraft Engine Overhaul Demand Forecasting using ANN. Manag. Prod. Eng. Rev. 2012, 3, 21-26. [CrossRef]

16. Cuk, E.; Chaparro, V. Methodology for optimizing manufacturing machines with IoT. In Proceedings of the 2018 IEEE International Conference on Internet of Things and Intelligence System (IOTAIS), Bali, Indonesia, 1-3 November 2018; pp. 90-96. [CrossRef]

17. Neugebauer, R.; Hippmann, S.; Leis, M.; Landherr, M. Industrie 4.0-From the Perspective of Applied Research. Procedia CIRP 2016, 57, 2-7. [CrossRef] 
18. Dremel, C.; Wulf, J.; Herterich, M.M.; Waizmann, J.C.; Brenner, W. How AUDI AG Established Big Data Analytics in Its Digital Transformation. MIS Q. Exec. 2017, 16, 81-100.

19. Lee, J.; Kao, H.-A.; Yang, S. Service innovation and smart analytics for Industry 4.0 and big data environment. Procedia CIRP 2014, 16, 3-8. [CrossRef]

20. Fisher, O.; Watson, N.; Porcu, L.; Bacon, D.; Rigley, M.; Gomes, R.L. Cloud manufacturing as a sustainable process manufacturing route. J. Manuf. Syst. 2018, 47, 53-68. [CrossRef]

21. Gao, R.; Wang, L.; Teti, R.; Dornfeld, D.; Kumara, S.; Mori, M.; Helu, M. Cloud-enabled prognosis for manufacturing. CIRP Ann. Manuf. Technol. 2015, 64. [CrossRef]

22. Lu, Y.; Xu, X. Cloud-based manufacturing equipment and big data analytics to enable on-demand manufacturing services. Robot. Comput. Integr. Manuf. 2019, 57, 92-102. [CrossRef]

23. Wang, X.V.; Xu, X.W. An interoperable solution for Cloud manufacturing. Robot. Comput. Integr. Manuf. 2013, 29, 232-247. [CrossRef]

24. Chen, B.; Wan, J.; Shu, L.; Li, P.; Mukherjee, M.; Yin, B. Smart Factory of Industry 4.0: Key Technologies, Application Case, and Challenges. IEEE Access 2018, 6, 6505-6519. [CrossRef]

25. Schermuly, L.; Schreieck, M.; Wiesche, M.; Krcmar, H. Developing an industrial IoT platform-Trade-off between horizontal and vertical approaches. In Proceedings of the 14th International Conference on Wirtschaftsinformatik, Siegen, Germany, 24-27 February 2019; pp. 32-46.

26. Bragança, S.; Costa, E.; Castellucci, I.; Arezes, P.M. A Brief Overview of the Use of Collaborative Robots in Industry 4.0: Human Role and Safety. In Occupational and Environmental Safety and Health; Arezes, P., Baptista, J.S., Barroso, M.P., Carneiro, P., Cordeiro, P., Costa, N., Melo, R.B., Miguel, A.S., Perestrelo, G., Eds.; Springer: Cham, Switzerland, 2019; Volume 202, pp. 641-650. [CrossRef]

27. Gonzalez, A.G.C.; Alves, M.V.S.; Viana, G.S.; Carvalho, L.K.; Basilio, J.C. Supervisory Control-Based Navigation Architecture: A New Framework for Autonomous Robots in Industry 4.0 Environments. IEEE Trans. Ind. Inform. 2018, 14, 1732-1743. [CrossRef]

28. Indri, M.; Grau, A.; Ruderman, M. Guest Editorial Special Section on Recent Trends and Developments in Industry 4.0 Motivated Robotic Solutions. IEEE Trans. Ind. Inform. 2018, 14, 1677-1680. [CrossRef]

29. Antonelli, D.; Stadnicka, D. Combining factory simulation with value stream mapping: A critical discussion. Procedia CIRP 2018, 67, 30-35. [CrossRef]

30. Ullah, A.M.M.S. Modeling and simulation of complex manufacturing phenomena using sensor signals from the perspective of Industry 4.0. Adv. Eng. Inform. 2019, 39, 1-13. [CrossRef]

31. Phillips, F.; Chang, J.; Su, Y. When do efficiency and flexibility determine a firm's performance? A simulation study. J. Innov. Knowl. 2019, 4, 88-96. [CrossRef]

32. Kusiak, A. Smart manufacturing. Int. J. Prod. Res. 2018, 56, 508-517. [CrossRef]

33. Tofail, S.A.M.; Koumoulos, E.P.; Bandyopadhyay, A.; Bose, S.; O’Donoghue, L.; Charitidis, C. Additive manufacturing: Scientific and technological challenges, market uptake and opportunities. Mater. Today 2018, 21, 22-37. [CrossRef]

34. Raza, A.; Haouari, L.; Pero, M.; Absi, N. Impacts of Industry 4.0 on the Specific Case of Mass Customization Through Modeling and Simulation Approach. In Customization 4.0. Springer Proceedings in Business and Economics; Hankammer, S., Nielsen, K., Piller, F., Schuh, G., Wang, N., Eds.; Springer: Cham, Switzerland, 2018; pp. 217-234. [CrossRef]

35. Weyer, S.; Schmitt, M.; Ohmer, M.; Goreck, D. Towards Industry 4.0—Standardization as the crucial challenge for highly modular, multi-vendor production systems. IFAC-Pap. 2015, 48, 579-584. [CrossRef]

36. Fraga-Lamas, P.; Fernández-Caramés, T.M.; Blanco-Novoa, Ó.; Vilar-Montesinos, M.A. A Review on Industrial Augmented Reality Systems for the Industry 4.0 Shipyard. IEEE Access 2018, 6, 13358-13375. [CrossRef]

37. Masood, T.; Egger, J. Augmented reality in support of Industry 4.0-Implementation challenges and success factors. Robot. Comput. Integr. Manuf. 2019, 58, 181-195. [CrossRef]

38. Stadnicka, D.; Antonelli, D. Implementation of augmented reality in welding processes. Technol. I Autom. Montażu 2014, 4, 56-60.

39. Wolniak, R.; Saniuk, S.; Grabowska, S.; Gajdzik, B. Identification of Energy Efficiency Trends in the Context of the Development of Industry 4.0 Using the Polish Steel Sector as an Example. Energies 2020, 13, 2867. [CrossRef]

40. Helo, P.; Hao, Y. Cloud manufacturing system for sheet metal processing. Prod. Plan. Control 2017, 28, 524-537. [CrossRef] 
41. Roblek, V.; Meško, M.; Krapež, A. A Complex View of Industry 4.0. SAGE Open 2016, 1-11. [CrossRef]

42. Szulewski, P. Koncepcje automatyki przemysłowej w środowisku Industry 4.0. Mechanik 2016, 7, 574-578. [CrossRef]

43. Bonilla, S.H.; Silva, H.R.O.; Terra da Silva, M.; Franco Gonçalves, R.; Sacomano, J.B. Industry 4.0 and Sustainability Implications: A Scenario-Based Analysis of the Impacts and Challenges. Sustainability 2018, 10, 3740. [CrossRef]

44. Nagy, J.; Oláh, J.; Erdei, E.; Máté, D.; Popp, J. The Role and Impact of Industry 4.0 and the Internet of Things on the Business Strategy of the Value Chain-The Case of Hungary. Sustainability 2018, 10, 3491. [CrossRef]

45. Hermann, M.; Pentek, T.; Otto, B. Design Principles for Industrie 4.0 Scenarios. In Proceedings of the 49th Hawaii International Conference on System Sciences (HICSS), Koloa, HI, USA, 5-8 January 2015; pp. 3928-3937. [CrossRef]

46. Olah, J.; Aburumman, N.; Popp, J.; Khan, M.A.; Haddad, H.; Kitukutha, N. Impact of Industry 4.0 on Environmental Sustainability. Sustainability 2020, 12, 4674. [CrossRef]

47. Abubakar, A.M.; Elrehail, H.; Alatailat, M.A.; Elçi, A. Knowledge management, decision-making style and organizational performance. J. Innov. Knowl. 2019, 4, 104-114. [CrossRef]

48. Industry 4.0: The fourth industrial revolution-Guide to Industrie 4.0. Available online: https://www.iscoop.eu/industry-4-0/ (accessed on 31 August 2020).

49. Rajapathirana, R.P.J.; Hui, Y. Relationship between innovation capability, innovation type, and firm performance. J. Innov. Knowl. 2018, 3, 44-55. [CrossRef]

50. Imran, M.; Hameed, W.; Haque, A. Influence of Industry 4.0 on the Production and Service Sectors in Pakistan: Evidence from Textile and Logistics Industries. Soc. Sci. 2018, 7, 246. [CrossRef]

51. Sevinc, A.; Gür, S.; Eren, T. Analysis of the Difficulties of SMEs in Industry 4.0 Applications by Analytical Hierarchy Process and Analytical Network Process. Processes 2018, 6, 264. [CrossRef]

52. McWilliams, A.; Parhankangas, A.; Coupet, J.; Welch, E.; Barnum, D.T. Strategic decision making for the triple bottom line. Bus. Strategy Environ. 2016, 25, 193-204. [CrossRef]

53. Short, M.; Rodriguez, S.; Charlesworth, R.; Crosbie, T.; Dawood, N. Optimal dispatch of aggregated HVAC units for demand response: An Industry 4.0 approach. Energies 2019, 12, 4320. [CrossRef]

54. Faheem, M.; Butt, R.A.; Raza, B.; Ashraf, M.W.; Begum, S.; Ngadi, M.A.; Gungor, V.C. Bio-inspired routing protocol for WSN-based smart grid applications in the context of Industry 4.0. Trans. Emerg. Telecommun. Technol. 2018, 68, 910-922. [CrossRef]

55. Huh, J.-H.; Lee, H.-G. Simulation and Test Bed of a Low-Power Digital Excitation System for Industry 4.0. Processes 2018, 6, 145. [CrossRef]

56. Ursic, D.E. Morphogenesis of Industrial Symbiotic Networks; Peter Lang: Berlin, Germany, 2020. [CrossRef]

57. Mileva Boshkoska, B.; Roncevic, B.; Ursic, D.E. Modeling and evaluation of the possibilities of forming a regional industrial symbiosis networks. Soc. Sci. 2018, 7, 13. [CrossRef]

58. Rocca, R.; Rosa, P.; Sassanelli, C.; Fumagalli, L.; Terzi, S. Integrating Virtual Reality and Digital Twin in Circular Economy Practices: A Laboratory Application Case. Sustainability 2020, 12, 2286. [CrossRef]

59. Brozzi, R.; Forti, D.; Rauch, E.; Matt, D.T. The Advantages of Industry 4.0 Applications for Sustainability: Results from a Sample of Manufacturing Companies. Sustainability 2020, 12, 3647. [CrossRef]

60. de Sousa Jabbour, A.B.L.; Jabbour, C.J.C.; Foropon, C.; Godinho Filho, M. When titans meet-Can industry 4.0 revolutionise the environmentally-sustainable manufacturing wave? The role of critical success factors. Technol. Forecast. Soc. Chang. 2018, 132, 18-25. [CrossRef]

61. Ding, K.; Jiang, P.; Zheng, M. Environmental and economic sustainability-aware resource service scheduling for industrial product service systems. J. Intell. Manuf. 2017, 28, 1303-1316. [CrossRef]

62. Fysikopoulos, A.; Pastras, G.; Alexopoulos, T.; Chryssolouris, G. On a generalized approach to manufacturing energy efficiency. Int. J. Adv. Manuf. Technol. 2014, 73, 1437-1452. [CrossRef]

63. Franco, M.; Pinho, C. A case study about cooperation between University Research Centres: Knowledge transfer perspective. J. Innov. Knowl. 2019, 4, 62-69. [CrossRef]

64. Rossetti, G.H.; Giraudo, F.; Murer, P.; Arcusin, L. Comparative Analysis of Product Development Process Management Models. Am. J. Ind. Eng. 2014, 2, 5-9. [CrossRef]

65. Magnusson, P.R. Exploring the contributions of involving ordinary users in ideation of technology-based services. J. Prod. Innov. Manag. 2009, 26, 578-593. [CrossRef] 
66. Sukhov, A.; Magnusson, P.R.; Netz, J. What is an Idea for Innovation? Serv. Innov. Sustain. Bus. 2019, $29-47$. [CrossRef]

67. Roozenburg, N.; Eekels, J. Product Design. Fundamentals and Methods; John Wiley \& Sons: New York, NY, USA, 1995.

68. Cooper, R.G. Stage-gate systems: A new tool for managing new products. Bus. Horiz. 1990, 33, 44-54. [CrossRef]

69. Cooper, R.G. What's Next? After Stage-Gate. Res. Technol. Manag. 2014, 57, 20-31. [CrossRef]

70. Amaral, D.; Rozenfeld, H.; de Araujob, C. A case study about the product development process evaluation. In Complex Systems Concurrent Engineering; Loureiro, G., Curran, R., Eds.; Springer: London, UK, 2007; pp. 211-218. [CrossRef]

71. Santos, K.; Loures, E.; Piechnicki, F.; Canciglieri, O. Opportunities Assessment of Product Development Process in Industry 4.0. Procedia Manuf. 2017, 11, 1358-1365. [CrossRef]

72. Lercher, H. Big Picture Das Grazer Innovationsmodell (Big Picture the Innovation Model); Anzeigen und Marketing Kleine Zeitung GmbH \& Co KG Verlagsort: Graz, Austria, 2019; Available online: https: //ssrn.com/abstract=2929258 (accessed on 24 March 2020).

73. Aristodemou, L.; Tietze, F.; O'Leary, E.; Shaw, M. A Literature Review on Technology Development Process (TDP) Models. In Centre for Technology Management Working Paper Series; Cambridge University Press: Cambridge, UK, 2019; pp. 1-31. [CrossRef]

74. Milewski, S.K.; Fernandes, K.J.; Mount, M.P. Exploring technological process innovation from a lifecycle perspective. Int. J. Oper. Prod. Manag. 2015, 35, 1312-1331. [CrossRef]

75. Berg, L.; Vance, J. Industry use of virtual reality in product design and manufacturing: A survey. Virtual Real. 2017, 21, 1-17. [CrossRef]

76. Lorenz, M.; Spranger, M.; Riedel, T.; Pürzel, F.; Wittstock, V.; Klimant, P. CAD to VR-A Methodology for the Automated Conversion of Kinematic CAD Models to Virtual Reality. Procedia CIRP 2016, 41, 358-363. [CrossRef]

77. Wolfartsberger, J.; Zenisek, J.; Sievi, C. Chances and Limitations of a Virtual Reality-supported Tool for Decision Making in Industrial Engineering. IFAC-Pap. 2018, 51, 637-642. [CrossRef]

78. Feeman, S.M.; Wright, L.B.; Salmon, J.L. Exploration and evaluation of CAD modeling in virtual reality. Comput. -Aided Des. Appl. 2018, 15, 892-904. [CrossRef]

79. Bickel, S.; Spruegel, T.C.; Schleich, B.; Wartzack, S. How Do Digital Engineering and Included AI Based Assistance Tools Change the Product Development Process and the Involved Engineers. In Proceedings of the 22nd International Conference on Engineering Design (ICED19), Delft, The Netherlands, 5-8 August 2019. [CrossRef]

80. O'Driscoll, E.; Kelly, K.; O’Donnell, G.E. Intelligent energy based status identification as a platform for improvement of machine tool efficiency and effectiveness. J. Clean. Prod. 2015, 105, 184-195. [CrossRef]

81. Schuh, G.; Doelle, C.; Mattern, C.; Modler, M.C. Studying Technologies of Industry 4.0 with Influence on Product Development using Factor Analysis. In Proceedings of the DS 91: Proceedings of NordDesign 2018, Linköping, Sweden, 14-17 August 2018; pp. 1-12.

82. Klippert, M.; Marthaler, F.; Spadinger, M.; Albers, A. Industrie 4.0-An empirical and literature-based study how product development is influenced by the digital transformation. Procedia CIRP 2020, 91, 80-86. [CrossRef]

83. Aguilar-Escobar, V.G.; Garrido-Vega, P.; González-Zamora, M.M. Applying the theory of constraints to the logistics service of medical records of a hospital. Eur. Res. Manag. Bus. Econ. 2016, 22, 139-146. [CrossRef]

84. Librelato, P.T.; Lacerda, P.D.; Rodrigues, L.H.; Veit, D.R. A process improvement approach based on the value stream mapping and the theory of constraints thinking process. Bus. Process Manag. J. 2014, 20, 922-949. [CrossRef]

85. Christophe, F.; Coatanea, E.; Bernard, A. Conceptual Design. In CIRP Encyclopedia of Production Engineering; Laperrière, L., Reinhart, G., Eds.; Springer: Berlin, Germany, 2014. [CrossRef]

86. French, M.J. Conceptual Design for Engineers, 2nd ed.; The Design Council: London, UK, 1999. [CrossRef]

87. Thompson, G. Improving Maintainability and Reliability through Design; Professional Engineering Publishing: London, UK, 1999.

88. Ulewicz, R.; Jelonek, D.; Mazur, M. Implementation of logic flow in planning and production control. Manag. Prod. Eng. Rev. 2016, 7, 89-94. [CrossRef] 
89. Yin, T.; Stecke, K.E.; Li, D. The evolution of production systems from Industry 2.0 through Industry 4.0. Int. J. Prod. Res. 2018, 56, 848-861. [CrossRef]

90. Asdecker, B.; Felch, V. Development of an Industry 4.0 maturity model for the delivery process in supply chains. J. Model. Manag. 2018, 13, 840-883. [CrossRef]

91. Troll, C.; Schebitz, B.; Majschak, J.-P.; Döring, M.; Holowenko, O.; Ihlenfeldt, S. Commissioning new applications on processing machines: Part I-Process modelling. Adv. Mech. Eng. 2018, 10, 1-11. [CrossRef]

92. Troll, C.; Schebitz, B.; Majschak, J.-P.; Döring, M.; Holowenko, O.; Ihlenfeldt, S. Commissioning new applications on processing machines: Part II-Implementation. Adv. Mech. Eng. 2018, 10, 1-12. [CrossRef]

93. Salkin, C.; Oner, M.; Ustundag, A.; Cevikcan, E. A Conceptual Framework for Industry 4.0. In Industry 4.0: Managing The Digital Transformation; Ustundag, A., Cevikcan, E., Eds.; Springer International Publishing: Cham, Switzerland, 2018. [CrossRef]

94. Rüssmann, M.; Lorenz, M.; Gerbert, P.; Waldner, M.; Justus, J.; Engel, P.; Harnisch, M. Industry 4.0. The Future of Productivity and Growth in Manufacturing. Technical Report; The Boston Consulting Group: Boston, MA, USA, 2015.

95. Oztemel, E.; Gursev, S. Literature review of Industry 4.0 and related technologies. J. Intell. Manuf. 2018, 31, 127-182. [CrossRef]

96. Paelke, V. Augmented Reality in the Smart Factory Supporting Workers in an Industry 4.0 Environment. In Proceedings of the IEEE Emerging Technology and Factory Automation (ETFA), Barcelona, Spain, 16-19 September 2014; pp. 1-4. [CrossRef]

97. Skórska, H. Systemy i zastosowania rzeczywistości rozszerzonej. Przeglad Mech. 2017, 1, 48-52. [CrossRef]

98. Yang, C.; Liu, J.; Chen, S.; Huang, K. Virtual machine management system based on the power saving algorithm in cloud. J. Netw. Comput. Appl. 2017, 80, 165-180. [CrossRef]

99. Leurent, H.; Betti, F.; Narayan, J.; de Boer, E.; Widmer, A.; Diaz, D.H.; George, K.; Marya, V.; Schmitz, C.; Kelly, R.; et al. Fourth Industrial Revolution Beacons of Technology and Innovation in Manufacturing; White Paper; World Economic Forum: Cologny/Geneva, Switzerland, 2019; Available online: http://www3.weforum.org/ docs/WEF_4IR_Beacons_of_Technology_and_Innovation_in_Manufacturing_report_2019.pdf (accessed on 23 March 2020).

100. O'Hare, J.; Cope, E.; Warde, S. Five Steps to Eco Design. Improving the Environmental Performance of Products through Design; Corporate Headquarters, Granta Design Limited: Cambridge, UK, 2015; Available online: https://www.grantadesign.com/download/pdf/FiveStepsToEcoDesign.pdf (accessed on 4 September 2020).

101. Alexiev, V. Hyundai and Kia Debut Virtual Reality (VR) Design Evaluation System. 2019. Available online: https://press.kia.com/eu/en/home/media-resouces/press-releases/2019/Hyundai-and-Kia-DebutVirtualReality-Design-Evaluation-System.html (accessed on 22 March 2020).

102. Butt, J. A Strategic Roadmap for the Manufacturing Industry to Implement Industry 4.0. Designs 2020, 4, 11. [CrossRef]

103. Fric, U.; Roncevic, B.; Ursic, E.D. Role of computer software tools in industrial symbiotic networks and the examination of sociocultural factors. Environ. Prog. Sustain. Energy 2020, 39. [CrossRef]

104. Encyclopedia of Business "Computer-Aided Design (CAD) and Computer-Aided Manufacturing (CAM)", 2nd ed. Available online: https://www.referenceforbusiness.com/encyclopedia/Clo-Con/Computer-AidedDesign-CAD-and-Computer-Aided-Manufacturing-CAM.html (accessed on 24 March 2020).

105. Sniderman, B.; Mahto, M.; Cotteleer, M.J. Industry 4.0 and Manufacturing Ecosystems Exploring the World of Connected Enterprises; Deloitte University Press: Westlake, TX, USA, 2016; Available online: https://www2.deloitte.com/content/dam/insights/us/articles/manufacturing-ecosystems-exploringworld-connected-enterprises/DUP_2898_Industry4.0ManufacturingEcosystems.pdf (accessed on 23 March 2020).

106. Gong, X.; Van der Wee, M.; De Pessemier, T.; Verbrugge, S.; Colle, D.; Martens, L.; Joseph, W. Energyand Labor-aware Production Scheduling for Sustainable Manufacturing: A Case Study on Plastic Bottle Manufacturing. Procedia CIRP 2017, 61, 387-392. [CrossRef]

107. Grywalski, M. DiaCom. Industrial Diaphragm Maker Achieves Seamless Transfer of Tool Design to Manufacturing with Solid Edge. Siemens PLM Software. 2019. Available online: https://media.plm. automation.siemens.com/solidedge/case-studies/Siemens-PLM-DiaCom-cs-52700-A11.pdf (accessed on 24 March 2020). 
108. Gontarz, A.M.; Hampl, D.; Weiss, L.; Wegener, K. Resource Consumption Monitoring in Manufacturing Environments. Procedia CIRP 2015, 26, 264-269. [CrossRef]

109. Matsuda, M.; Matsumoto, S.; Noyama, N.; Sudo, Y.; Kimura, F. E-catalogue Library of Machines for Constructing Virtual Printed-circuit Assembly Lines. Procedia CIRP 2016, 57, 562-567. [CrossRef]

110. Mawson, V.J.; Hughes, B.R. The development of modelling tools to improve energy efficiency in manufacturing processes and systems. J. Manuf. Syst. 2019, 51, 95-105. [CrossRef]

111. Bugno, Ł.; Szalaty, A. Praca w zintegrowanym środowisku CAD/CAM i jej wpływ na jakość oraz czas produkcji. Przegląd Elektrotechniczny 2017, 93, 68-69. [CrossRef]

112. Mearian, L. Inside Ford's 3D Printing Lab, where thousands of parts are made. ComputerWorld. 4 June 2014. Available online: https://www.computerworld.com/article/2490192/emerging-technology-inside-ford-s-3dprinting-lab-where-thousands-of-parts-are-made.html (accessed on 23 March 2020).

113. Roszak, A. Przemysł 4.0.—Definicje, znamiona, efekty. 2018. Available online: https://mensis.pl/przemysl-40-definicja-znamiona-efekty/ (accessed on 24 March 2020).

114. Vissak, T. Recommendations for Using the Case Study Method in International Business Research. Qual. Rep. 2010, 15, 370-388.

115. Ragin, C. What Is a Case?: Exploring the Foundations of Social Inquiry, 11th ed.; Cambridge University Press: Cambridge, UK, 2000.

Publisher's Note: MDPI stays neutral with regard to jurisdictional claims in published maps and institutional affiliations.

(C) 2020 by the authors. Licensee MDPI, Basel, Switzerland. This article is an open access article distributed under the terms and conditions of the Creative Commons Attribution (CC BY) license (http://creativecommons.org/licenses/by/4.0/). 